\title{
She'll wake up one of these days and find she's turned into a Tongan: Agricultural Trade in the Kingdom of Tonga
}

\begin{abstract}
In November of 2012, the Government of Tonga announced it had put $\$ 1$ million Tongan pa'anga into setting up a fund for exporting taro, tapioca, watermelon, and yam targeted for sale on the New Zealand market. It took three months for this public notice to reach independent media, getting published by local news outlets in February the following year. Tongan farmers in villages and districts made no rush to grab the state's money. It was in fact a loan that had to be repaid and was not intended for them. The middle men, meaning export businesses that bought produce from farmers to sell overseas were the benefactors. The development logic unfolded: If the middle man borrowed from the government to pay the farmer for his fruit and vegetables, he could trade these commodities with the New Zealand importer, thus, making money to pay back the loan as well as earning a profit.

The selling point was overseas trade. Exports could resuscitate the broken farming industry gagging for air in the broke Kingdom of Tonga. In reality, it did not look to happen how the Tongan state imagined their plan would take off.
\end{abstract}

Teena Brown Pulu has a PhD in anthropology from the University of Waikato. She is a senior lecturer in Pacific development at AUT University. Her first book was published in 2011, Shoot the Messenger: The report on the Nuku'alofa reconstruction project and why the Government of Tonga dumped it. 
What was difficult about trading taro, tapioca, watermelon, and yam to New Zealand? These were crops that had established niche markets as tropical produce on the New Zealand market. Inside this small island developing state would the real impediment please stand up?

\section{The true neighbour}

The true neighbour will risk his position, his prestige and even his life for the welfare of others.

\section{Martin Luther King Jnr}

In spring of 2011 I asked Lord Ma'afu, the Minister for Lands and Environment at the Government of Tonga, if I could visit Vaini. It was the main village on his estate with a population of 2,976. Like most villages in the South Pacific Islands, Vaini had a youth bulge, meaning it was a fast growing population of young people and children overstraining limited household incomes because there were few jobs outside of the public service, which was the country's largest employer. I wanted to speak with local farmers. Ma'afu was the noble of Vaini and Tokomololo, two villages in the central district of Tonga's main island, and his people were farming communities.

This was the common sense division of labour according to what part of Tonga you came from; Tongans in the smaller islands fished for a living, and the rural villages on the main island farmed. The outer islanders of the Ha'apai and Vava'u groups generally thought that the small land size of their atolls constricted farming productivity. They could make a better living from fishing because the sea was their garden, an extension of lush land. By comparison, villages were pastoral on the main island of Tongatapu, which was the largest landmass in the Kingdom of Tonga's 176 atolls of which 52 were inhabited. 
Tongatapu people saw farming as the origins of livelihood. This was especially so for the villages on nobles' estates in the rural districts, some distance away from Nuku'alofa's overcrowded suburbs where squatter settlements grew on the outskirts of town in Sopu and Pa Tangata. In the commercial world, exporting agricultural crops was the country's baseline economy, and at the subsistence level of day-to-day survival in a small island developing state, growing food was the effective way for ordinary Tongan families to support themselves.

What I had asked Ma'afu, a high-ranking noble and senior cabinet minister, was to get me access to a restricted area, the agricultural sector, so I could do field research. Inside the farmers and exporters border I had to have permission to be there as a half-cast woman from the younger generation born in New Zealand not Tonga; a woman who did not speak Tongan as a first language and was considered in the islands to dress and behave like a Palangi, not a Tongan; a woman who did not labour on an 'uta in Tonga to feed my children; a part Tongan woman who had no blood connection to Vaini.

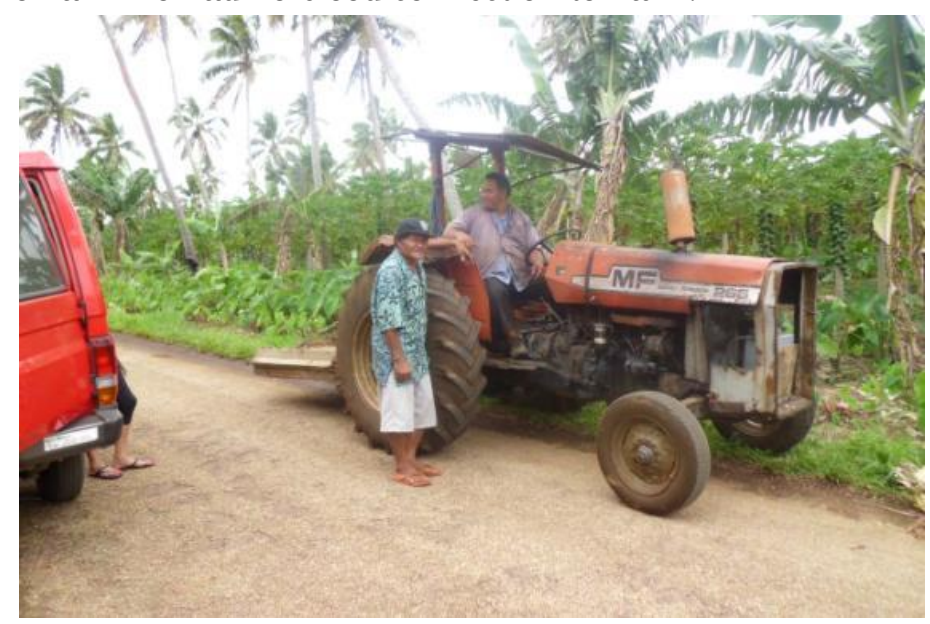

Local farmers from Vaini, a rural village on the estate of Lord Ma'afu in the Kingdom of Tonga's central district. 
Ma'afu got me into his village community. He set up meetings with farmers, exporters, and bureaucrats in the Ministry for Agriculture and Fisheries, some who were guarded about speaking, but saw me because he had asked them and they trusted his judgement. I watched him communicate to his networks, seeing how he skilfully crafted openings for me to gain entry into an industry ruled by rich men and poor men, but men all the same, in this hierarchical and patriarchal island Kingdom. From observing Ma'afu, he taught me two important lessons about myself in relation to Tonga.

The first was on doing insider research when, as in my "predicament of culture," one is an insider and outsider of their ancestral homeland (Clifford, 1988). The second was the difficulty of "long-distance nationalism" when overseas Tongans desire involvement in the homeland's political life, but their everyday reality is that they do not live in Tonga (Charim, 2007). By not living here, overseas Tongans do not have to brunt surveillance by the Tongan state and take bullying and condemnation from government officials, including the prime minister, cabinet ministers, and parliamentarians, for expressing political opinions that go against the grain. 


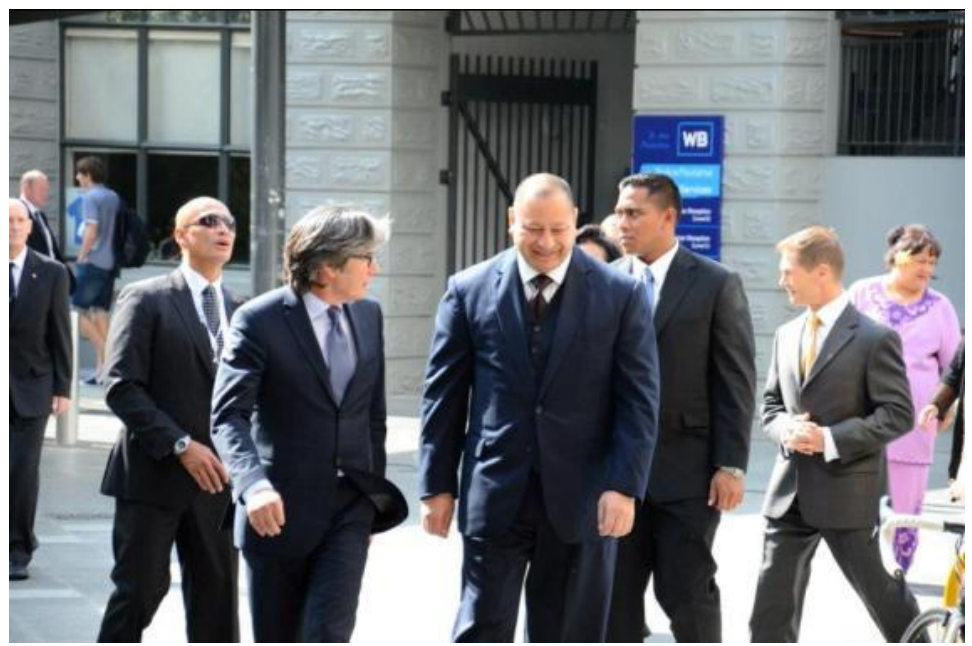

King Tupou VI of Tonga (right) being escorted onto Auckland University of Technology campus by Vice Chancellor Derek McCormack (left) during a 1-hour visit organised by NZ Ministry of Foreign Affairs on 27 February 2013.

This work unravels the relevance of insider research and long distance nationalism in examining colonial associations that persist inside Tonga's hierarchy in the 21 st century (Cooper and Stoler, 1997). It is a story I have written myself into as an anthropologist who researches inside my own people's lives; as a Tongan woman of mixed-blood born in New Zealand who sustains long distance relationships with loved ones in my ancestral homeland; and, as an intellectual who knows the emotional ties and loyalties to an origin people and place can inspire what we stand for, fight for, believe in.

At the advent of modern Tonga, the relationship between the ruling class and European traders was about economics and preserving the constitutional monarchy by consolidating the state and the church (Latukefu, 1974). Historically, their connection manufactured the exclusion of the commoner class from acquiring leases for large areas of land, and thereby 
heading the business sector founded in plantation farming and trading produce. The division of labour was stratified: Landlords leased land, Natives farmed on small-scale plots, and the Europeans took care of business by trading for profit. In the South Pacific, this pattern of social and economic transaction between traditional rulers and white migrants was prevalent during the years of colonial administrations, before the enactment of political independence in the 1960s and 70s (Oliver, 1989; Howe, Kiste and Lal, 1994).

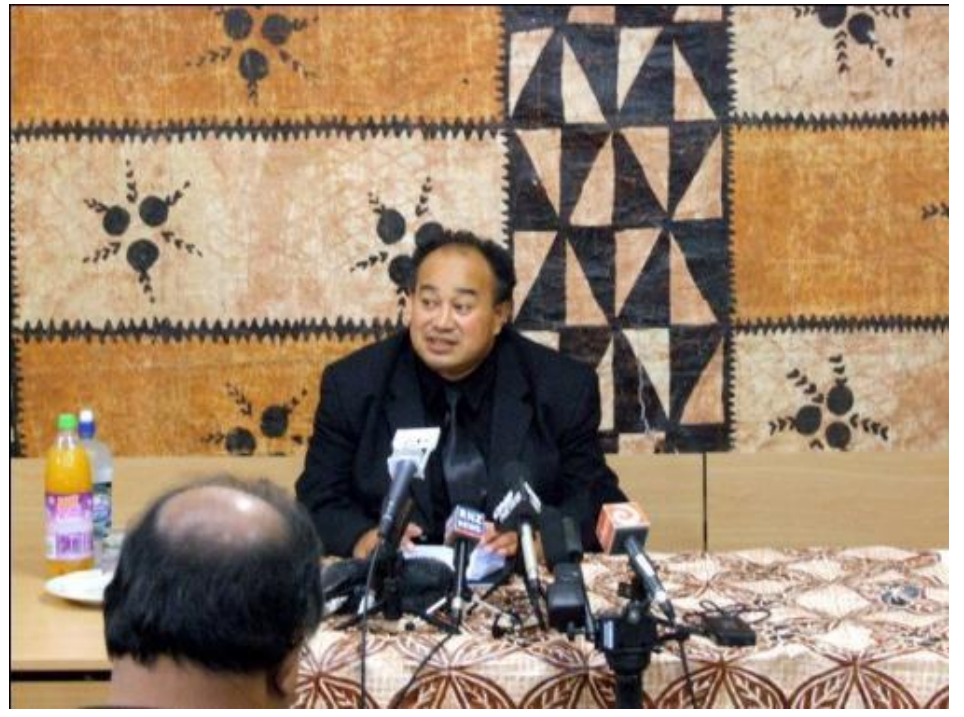

The late Baron Fielakepa, noble of Havelu'loto, delivering a press conference in Auckland, New Zealand about the late King Taufa'ahau Tupou IV's passing in September of 2006.

Tonga's social and economic hierarchy shows that colonialism has bred a peculiar kind of co-dependency between traditional rulers and certain families that trace their ancestry to foreign traders, businessmen, and administrators (Bhabha, 1997). Specific to agricultural trade, why have individuals personified as the descendants of foreigners that 
were at the forefront of commerce in days gone past, lasted through the industry's financial demise to remain the country's top exporters? (van der Grijp, 1997). Contrariwise, why have ordinary Tongans without a privileged family history in business not excelled at exporting so they have collective clout to dissolve the monopoly of a handful of men? (Firth, 2000). In Tonga, a small insular society where the majority of the country's wealth is produced by a limited number of small to medium-sized enterprises (SMEs) and consumed by few families who are household names, how can the power structure transfer the exporting advantage to village farmers at the rear end of supply chain economics? (Murray, 2001; Herndon, Ash and Pollin, 2013; Pollin and Ash, 2013).

\section{I am mixed-blood}

Back ten years ago when I was a fledgling $\mathrm{PhD}$ student in anthropology at the University of Waikato, Sosefo Havea remarked that I was lucky I had access to the nobility because he did not have that, and it made field research in Tonga hard if you were not connected to the nobility. He was intimating around me being a half cast, the direct descendant of a colonial trader great-grandfather of British origin who had settled in Tonga with his wife and children during the first quarter of the 20th century (McGregor, 1993). Sosefo was a middle-aged migrant Tongan man doing a $\mathrm{PhD}$ in political science at Victoria University of Wellington.

I carried the kind of cultural discomfort traced to an era of Tonga's modern history. It was assembled by the Kingdom of Tonga's colonial relationship with the United Kingdom as a protectorate state, a small island developing state under imperial control (Cooper and Stoler, 1997). This attachment to an empire seen as paternal and protective saw that all things British were deemed superior to the South Seas Native (Howe, Kiste, and Lal, 1994). 
In New Zealand, I was raised by parents born in Tonga; parents who did not use the Tongan language around me because they insisted that I speak, read, and write proper English; parents who did not push Tongan culture and church on me because they believed it would handicap my aptitude in Western intellectual thought; parents who were fearful that if traces of Tonga were not erased from me, it might disable my ability to excel in the New Zealand education system and become accepted by my white peers as equal in brainpower (Dabashi, 2013).

My half-cast mother, whose father was a British citizen, had his children conferred with British citizenship through the South Pacific office of the British High Commission, which at that time was based in Port Moresby, Papua New Guinea. Despite the fact his children were born in Tonga, paternity laws afforded them British citizenship and United Kingdom passports. It was the accepted remedy for minimising crosscultural contamination in the colonies. In Tonga, children born in wedlock inherited the father's national identity. Being born and raised in New Zealand, this ruling on paternity and national identity was not strictly enforced on me (Clifford, 1988).

Despite the fact my father was Tongan by ethnicity and citizenship, mum stressed I was a New Zealander not a Tongan, and that the full-blooded Natives back in the islands would never accept me as a Tongan. She would scold; why on earth would I want to be from a poor uneducated family in Tonga; this was not the country I came from. Years later, I realised as an adult that my mother was repeating the social code that her Native Tongan mother had applied to her halfcast children of mixed-race in the post-World War II Pacific Islands.

Race and racism are entangled in Tonga's colonial class and caste system which halves and carves whole people into incomplete pieces, blood fractions, broken fragments (Marsh, 2009). I embodied the modern social experiment bred 
overseas and engraved by legends of the mixed-blood, the middle-class half cast writing, reading, and speaking English in the persona, accent, and idiom of white people, while tracing an island heritage to a British gentleman married to a Native woman in the South Seas. It was an inherited condition passed down to me by maternity.

Everett Stonequist, an American sociologist, published an influential book in 1937 which analysed the lived experience of what he called, The Marginal Man: A Study in Personality and Culture Conflict. Stonequist mapped out the conflicted reality that people of mixed-blood, the half cast Natives born in the European colonies of the 19th and 20th centuries, endured through, quarrelled with, and made collective sense of. His "marginal man" theory appeared in a 1935 essay, prior to the book's publication.

The marginal man arises in a bi-cultural or multicultural situation. The natural desire of the mixedblood is to advance toward the group occupying the higher status. He may be forced to accept the status of the lower group, possibly becoming their leader. He may be rejected by both groups. Where accommodation, rather than conflict, prevails, the mixed-blood may constitute a middle class. With intermarriage the mixed-blood approximates nearly to the status of the dominant race. The marginal individual experiences what Du Bois has analysed as "double consciousness." It is as if he regarded himself through two looking-glasses presenting clashing images. (Stonequist, 1935, p. 1).

Acts of collective sense making in light that "researchers now commonly discuss their own experience in their research" is what I focus on (Ellis and Berger, 2003, p. 467). However, different to Carolyn Ellis and Leigh Berger's (2003) take that it is commonplace for researchers to write "their own experience" 
of doing research, I am the subject of research. I am a Native of Tonga. As well, I am the researcher. This puts me in a much closer position to, and a more intimate relationship of, writing myself in relation to my people as the subject being researched.

But I am, in the social imaginary, a Native hybrid of Tonga. Therefore, my questioning of social boundaries is straightforward to ask but problematic to answer. By imagining the half cast, by actively constructing the character and category of mixed-blood people affiliated to the colonial era of Tonga's protection under Britain, how is the social mobility of this sub-group made sense of by Tongans who identify as full-blooded Natives alongside the bearers of the identity classification themselves?

Sosefo Havea's reflexive statement revealed he considered my half cast station in Tonga got me inroads to "the group occupying the higher status," that being the nobility (Stonequist, 1937, p. 1). My mother, by comparison, perceived that in New Zealand "the group occupying the higher status" were white New Zealanders not the Native Maori indigenous to this country, but rather, Pakeha or Palangi descended from British colonial settlers as she was.

To see myself "through two looking-glasses presenting clashing images" is captured in this moment of retelling how the judgement of others canvasses societal locations in which people of mixed blood are permitted to exist in nearby proximity to the centre of power (Stonequist, 1937, p. 1; Austin, 1993). Thus, it is the resilience of the half cast characterisation and classification in how it is familiarised and housed next to Tonga's traditional rank and hierarchy of fullblooded Natives, which is interwoven in my story as a researcher and the researched subject (McGregor, 1993; Williams 1995).

Identity tales that Sosefo Havea and my mother spun about the social mobility of mixed blood intersected on a common belief. In this context, the half cast can almost but 
never quite arrive at "the status of the dominant" ruling class in Tonga, or in New Zealand, "the status of the dominant race" (Stonequist, 1937, p. 1; Cox, 1945). Implicitly there lies an expectation that the role of the half caste is to irrefutably support the status quo. The social hierarchy hangs on the ruling class, or the dominant race, remaining in power.

In Tonga, the monarchy and nobility stay at the apex by exercising social control. This is a system of protecting and policing boundaries that rank and order various groups under them (Oliver, 1989). A double-bind materialises in that mixedblood can get close, but it can never get uppity. For the half cast to be looked upon favourably by the ruling class in the interest of holding the financial and resourcing advantage over others further down the pecking order, involves politely nodding to the top and not rocking the boat. Effectively it means never getting above the designated station by transgressing racial and class boundaries of society.

\section{Hybridity trouble}

At the end of the 20th century and hinging on the 21 st, Sarah Ahmed published an article with an attention grabbing name: "She'll wake up one of these days and find she's turned into a nigger" (Ahmed, 1999, p. 87; Larsen, 1929, p. 171). She borrowed the heading from a line in Nella Larsen's 1929 novel, Passing, which told Larsen's personal story of being mixedblood, a woman of Black West Indian and Danish European parentage born in late 19th century America. Larsen's book highlighted racism and sexism because these were the cornerstones of discrimination which defined, and confined, her identity and what she represented to the dominant race of white Americans and the ethnic minority of Black Americans. She was hybrid; neither white nor black, but dislocated, displaced, and disarticulated in between binaries, in between two separate colours, classes, and communities. 
Ahmed's article detected there is "an assumption that a white subject cannot possibly become black" (1999, p. 87). The impossibility of white people turning into black people, or desiring to be black people, was historically interpreted as a ludicrous proposition, or acted out in a satirical form of jesting about the impossible. This was captured in Larsen's novel when a conversation between two black women saw one sarcastically mock a white woman: "She'll wake up one of these days and find she's turned into a nigger" (Ahmed, 1999, p. 87; Larsen, 1929, p. 171).

For people of mixed race, attempting to pass as white people, or black people, can ignite animosity, loathing, and illwill from both racial groups. They can be reacted against with hostility, as if they are illegal border crossers subverting the racial boundary between white and black. Jan Pieterse described the cross-pollination of "different cultures" in multiracial people as "hybridity." By Pieterse's analysis, it is the fact that "hybridity problematizes boundaries," disturbs a border's permanence, unsettles the taken for granted normality of race and class, messes up its matter-of-fact stability and regularity, which makes hybridity significant (Pieterse, 2001, p. 219).

What hybridity means varies not only over time but also in different cultures and this informs different patterns of hybridity. Then we come back to the original question: so what? The importance of hybridity is that it problematizes boundaries. (Pieterse, 2001, $p$. 219).

In the field of agriculture, Dutch anthropologist Paul van der Grijp's 1997 article identified a new variety of Tongan hybrid. He named it Tongan and Japanese, a different mixture to the well-known Tongan and European breed. This European academic from the northern hemisphere fumbled to make sense of how a part Japanese squash exporter in the 
1990s fitted into the Tongan "ethnoscape," and by floundering, crashed into race and racism (Appadurai, 1996). Perhaps inadvertently, van der Grijp's analysis reinforced an amplified stereotype that Asians are aggressive, belligerent, and unethical in business compared to the submissive, respectful, naïve Pacific Islander.

Nakao, however, is part of the noble Ma'afu family. His mother was the only sister of the Ma'afu titleholder. This family connection is how Nakao received a large coconut plantation that he later used for other cash crops, such as squash. In his own words Nakao emphasizes his family link with the noble Ma'afu family through his mother. Nakao's father, however, is Japanese, born in Japan, who only came to Tonga in later life. This fact may be of crucial importance in understanding his success in business, especially now with the squash export trade to Japan. Although Nakao and Moengangongo are of noble blood and Nakao took advantage of this by accumulating much land, none of the leading squash exporters holds a title. (van der Grijp, 1997, p. 44).

van der Grijp's one-liner, "Nakao's father, however, is Japanese, born in Japan," gave rise to the assumption that "this fact may be of crucial importance in understanding his success in business." The author confirmed his suspicion about Asian hybridity by noting that "although Nakao and Moengangongo are of noble blood ... Nakao took advantage of this by accumulating much land" (van der Grijp, 1997, p. 44). There is a spiralling deduction which passes judgement on Nakao's Japanese ancestry.

Opposed to his Tongan heritage, the Asian blood has fostered his business behaviour in Tonga's agricultural industry. In this context, the author considers that by principles of Tongan culture, his mind-set is unscrupulous 
and expressly Japanese. This is validated by intimating that different to full-blooded Tongans such as Moengangongo, Nakao "took advantage" of his high-ranking blood ties to the noble Ma'afu line to grab as much land as he could for his personal profitmaking as a squash trader to the Asian market.

\section{Free trade fear}

A distinct rationale had shaped van der Grijp's allusion that Nakao's business behaviour crossed the ethnic border from Tonga to Asia arriving in Japan, where his manner of doing business was culturally suited, rather than being put to work in a small island developing state. His article's title was telling; an examination of the Leaders in Squash Export: Entrepreneurship and the Introduction of a New Cash Crop in Tonga. What he concluded is that "none of the leading squash exporters holds a title," meaning that the traditional landowning class of nobles were not the middle-class entrepreneurs making money from cash-cropping squash for the Asian market (van der Grijp, 1997, p. 44).

His point was that a power shift had occurred, one that reflected a modern world system propelled by capitalism (Wallerstein, 1976). This was the model of Western Europe's transition from an agricultural-based economy to an industrialised society in which the largest producers of wealth held financial power and political influence over the state's affairs. What van der Grijp had overlooked is that the advantageous positioning of mixed-blood businessmen was understandable given that in Tonga's colonial era, traders were foreigners, and their half cast offspring were socially expected to continue dominating the business sector.

Picking up on 'Epeli Hau'ofa's anxiety published in two essays, The New South Pacific Society and Our Sea of Islands, van der Grijp focused on the new elite which had grown powerful inside South Pacific states (Hau'ofa, 1987, 1993, 2008). Recognised leaders were now businessmen, local 
entrepreneurs running small to medium-sized enterprises (SMEs) at a commercial profit. In essence, he presented a counter argument to the 1990s acceptance that trade liberalisation represented the West's standard policy for economic expansion. Through integrated regional economies in which multinational companies were given license to dictate the market, it was anticipated that developing regions, such as the South Pacific, would uncritically follow along. In particular, Australia and New Zealand's dominance over their Third World neighbours had forced the Pacific Islands to dismantle state owned enterprises and regulated economies, opening up their borders for private sector entrepreneurs to control the business sector.

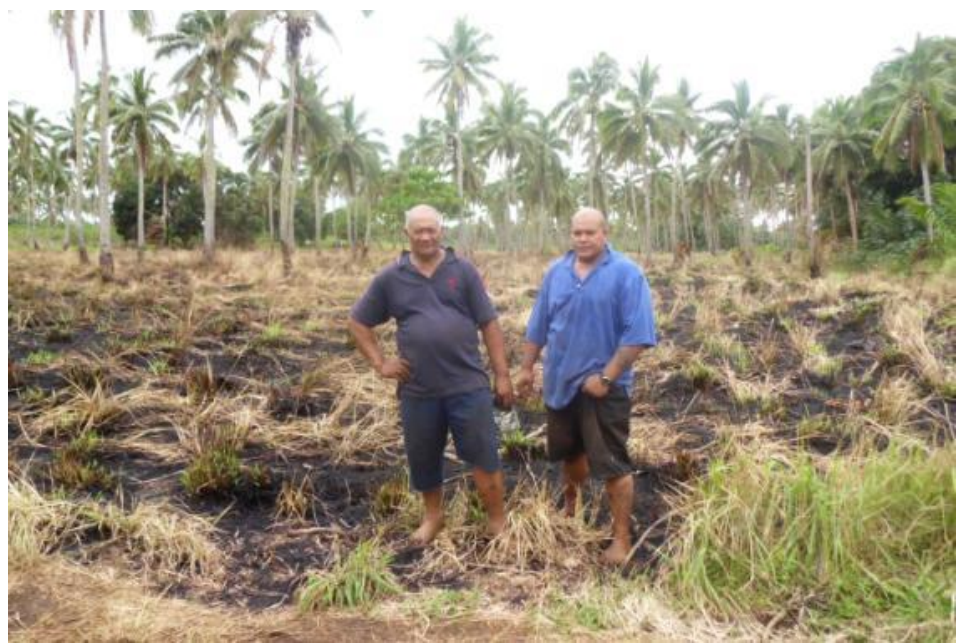

A Vaini farmer and his son preparing their plot for growing watermelon in the Kingdom of Tonga's central district.

The free trade fear for small island developing states was that their economies were made vulnerable to a sea of dependency. Unable to trade equitably with developed countries, the internal structure of a deregulated economy in the Pacific Islands favoured financial increases for a few 
businessmen, more so than businesswomen. The real cost to society was that the redistribution of limited wealth across class groups to ease poverty, instead of entrenching it, did not take effect. Thus, the glaring gap between the rich minority and poor majority, a trademark of the developing country dilemma, was exacerbated.

\section{Pacific parliamentary forum}

Sixteen years on from van der Grijp's 1997 publication, Papua New Guinea's governor of Oro Province, Gary Juffa, spoke up strongly at the inaugural Pacific Parliamentary and Political Leaders' Forum. Organised by the New Zealand Government in Wellington from the 18th to the 22nd April 2013, New Zealand's agenda was to manoeuvre the forum to rein in Pacific economies under an integrated region. Overruled by New Zealand and Australia in collaboration with the United States via the World Bank, and overrun by free trade, was not how Pacific leaders had envisioned a South Pacific future. Reacting to the joint call from World Bank economist Tim Bulman and New Zealand Minister of Finance Bill English for Pacific Island governments to economically reform, downsize bureaucracies, privatise assets, deregulate economies, and adopt free trade agreements that were pro-foreign investment, Juffa argued back.

The New Zealand Government tag-teamed with the World Bank to table an austerity policy passed off as economic growth measures which they considered necessary for the world's poor countries (Pollin and Ash, 2013; Herndon, Ash and Pollin, 2013). Aggravating longstanding power and wealth disparities between states of the Pacific Rim and the Pacific Islands, Juffa's objection was straight and sharp. Economic development for whom? In an unequal power relationship between developed and developing countries, who really benefits? (Sykes, 2010; Sergel and Scott, 2013a). 
"A few selfish and greedy people" had caused the financial crisis, and those pushing free trade in the Pacific came from wealthy protected economies in the west. "Every time the Pacific rises up to say something, Western countries say we give you aid, and we become spectators in our own land," he said. "We cannot let Western countries pull wool over our eyes - and Australia and New Zealand produce the finest wool in the world." (Sergel and Scott, 2013b).

Papua New Guinea's governor had subverted the Western gaze (Bender, 1999). Coining a colloquial expression common to Australian and New Zealand everyday English, pull the wool over our eyes, his comments stared down the New Zealand finance minister's paternalistic tone that "we have a better understanding of the challenges that you are grappling with, leaders in your economies, than almost any other country. And there's no point in us feeling like we're doing well if the 6 million people in our sort of near part of the Pacific aren't doing well" (Sergel and Scott, 2013b).

Juffa's cutting criticism was indignant: Free trade was a scam shamelessly self-promoted by Australia and New Zealand, the region's free trade scammers preying on Pacific Island markets to advance their economic growth under the pretence of aid and development. For Bill English to propose "we have a better understanding of the challenges that you are grappling with" made a wrongful assumption that attendants gathered at the Pacific Parliamentary and Political Leaders' Forum did not know the history of their modernity, their coming of age in international politics as sovereign states constituting the South Pacific region.

Some New Zealand politicians and parliamentary reporters congratulated themselves for organising a maiden talkfest they desired to be instituted as an official Pacific parliament by permission of the New Zealand government's financial and diplomatic patronage (Haas, 2013d; Hayes, 2013). Meanwhile 
at the same assembly, an adjustment to how Oceania valued ownership and representation was unveiled. On this point, Vanuatu Minister of Lands and Energy, Ralph Regenvanu, announced his country's stand against the politics and polemics of free trade and the privatisation of collective land ownership.

At once, the sentiment fortifying Gary Juffa's words were echoed and evoked: "Every time the Pacific rises up to say something, Western countries say we give you aid, and we become spectators in our own land" (Sergel and Scott, 2013b). It appeared that the political tide had turned in which Melanesian leaders were heading an effort to reclaim decisionmaking autonomy, a small island developing state's economic sovereignty over "people and land," "our only resource," as Regenvanu's voice affirmed (Sergel and Scott, 2013c).

One of my priorities is to reform land law to really enshrine customary tenure over land. New Zealand, Australia and the World Bank are saying that we need to get away from that, but I totally disagree. We need to enshrine it so that cultural land-owning groups or land-stewarding groups never lose control of the resource - because in the Pacific land is our only resource, people and land. (Sergel and Scott, 2013c).

While Juffa publicly opposed free trade with the backing of Melanesian leaders, "Guam Republican Minority Whip Thomson Morrison," and Samoa's only female cabinet minister Fiame Mata'afa, Regenvanu advanced the case that "customary land tenure" was the South Pacific safeguard from the privatisation of land and assets (Sergel and Scott, 2013b, 2013c). Attending the forum were six men representing the Kingdom of Tonga's parliamentary contingent of one speaker, three cabinet ministers, and two opposition members. They remained quiet. Tonga made no definite stand on the free trade versus land sovereignty debate. 


\section{Trade game}

For Tongan male members of parliament from a patriarchal Kingdom not to speak up on "customary land tenure" gave off a strained and strange silence (Sergel and Scott, 2013c). The Kingdom of Tonga afforded rights to male heirs, privileging male hereditary succession to land, and stating unequivocally by law that, "Every estate (tofia) and allotment (api) is hereditary according to the prescribed rules of succession" (Tonga Land Act, 1988, p. 13). Tongan land law provided an exemplar of Regenvanu's call for Pacific Island governments "to really enshrine customary land tenure over land" as the panPacific approach to disabling Western economic reform principles from going viral (Sergel and Scott, 2013c).

The very sale of land was proscribed in the Tonga Land Act 1988 in that, "Every verbal or documentary disposition by a holder of any estate (tofia) or allotment (api) which purports to effect a voluntary conveyance, an out-and-out sale, or a devise by will of such estate or allotment is null and void" (Tonga Land Act, 1988, p. 13). There was speculation that political undercurrents had thrown the Tongan teamwork off-balance (Kennedy, 2012).

With Lord Fakafanua, a young noble of twenty eight years old as the Speaker of Parliament, the delegation leadership was largely inexperienced, media clumsy, and politically naïve. The New Zealand media snapshot of Lord Fakafanua was that he believed regional cooperation between Pacific Island countries had "higher priorities than work on gender equality" (Haas, 2013c). This gave the New Zealand public a performance indicator oriented in Western values which measured how the Kingdom of Tonga was transitioning into the region's newest democracy (Campbell, 2011).

But in real life, Tonga was busy working through "a new family protection bill designed to stop male domestic violence against women and children" (Matangi Tonga, 2013c). The significant news saturating local media was how to value women's lives by correcting bad patterns of behaviour. 
Tongan reporters covered widespread support for the bill from women and men in journalism, non-government organisations, churches, the police, the education sector, as well as health and law professionals. Somewhere in the official parliamentary line Fakafanua conveyed in Wellington, the political climate barometer was disengaged from Tonga's changing social values as they took hold in the country.

Fakafanua, the Speaker of Parliament concluded that Tonga and the region held "higher priorities" than land and women (Haas, 2013c). Added to the mix was Sangster Saulala, Tonga's Minister for Agriculture and Fisheries, advocating for open borders prepared to trade on the New Zealand market. Between the Tongan parliamentary contribution to New Zealand's high-level regional forum on what was most relevant to South Pacific development, and social change being validated in everyday life, a Tongan political lens from which the country saw itself reflected in the world was none the clearer.

One factor that did emerge from Tonga's participation at the Pacific Parliamentary and Political Leaders' Forum was the Government of Tonga perceived this five-day summit as an export opening. Saulala's discussion sought progress on levelling disproportionate trade between Tonga and New Zealand.

Tonga has invested TOP 1 million on an agricultural fund so government can support growers by government dealing directly with exporters. Another budget will pay for another initiative - the recruitment of a Tongan trade representative in Auckland the agriculture minister said. Sangster Saulala has also set up an agricultural sector group which appears to overshadow the Tongan Growers Federation, which used to claim 1200 members. (Haas, 2013b). 
The Tongan state intervention Saulala outlined was simply that; a temporary bureaucratic interruption to unfreeze the blockage in the system, add investment lubricant, and then refreeze the system back into the original model. By no means was Tonga's Minister for Agriculture and Fisheries envisioning a radical affront to free market trade like Melanesian leaders; nor was he in favour of collapsing the regime of international and regional trade agreements where Tonga's production power was of low financial value.

The real interference played out through Saulala's organisation of a counter-group to check-and-balance the Tongan Growers Federation power over the New Zealand market by promoting itself as the business hub representing the majority of farmers. Obviously the minister was informed of disgruntled farmers, particularly from Hahake. Tongatapu's eastern district had village cooperatives disputing the Tongan Growers Federation monopoly of Tonga's supply chain, whereby locking down the middleman territory the sale price on commodities could be driven down.

'Aisake Eke, an independent Member of Parliament for Tongatapu 5 who was included in Tonga's parliamentary delegation to Wellington, commented that acquiring and sustaining market "connections" with New Zealand importers posed a trade obstacle for Tongan farmers.

We have problems getting connections with some of New Zealand's private sector retailers who might buy Tongan exports. (Haas, 2013a).

Eke's observation, in all its simplicity, uncovered a highly politicised environment which couched Tonga's agricultural industry. There was an acute disjuncture between Tongan farmers and the market represented by companies importing taro, tapioca, watermelon, and yam to Auckland, New Zealand. Traditional Tongan trade was transacted through an informal system of economy. By this, village cooperatives sold 
containers of fresh and frozen produce on church sites, to church congregations and extended family networks, and at flea-markets in Auckland suburbs with high Pacific Islander populations. But the commercial market was inaccessible to farmers' collectives. New Zealand distributors to supermarket franchises purchasing large volumes of tropical commodities only engaged in business with agents, middlemen, and elite growers and exporters.

The inquiry was clear-cut: If reforming Tonga's agricultural industry meant creating an equitable business environment for farmers to have access to markets and fair trade, then how might government achieve this? The Tongan state had a twofold strategy. First, new exporters would be developed, as opposed to established companies ruling the roost. Second, it was considered that taro, tapioca, watermelon, and yam would infiltrate the New Zealand market by an Auckland-based trade representative mediating between importers, exporters, and state quarantine regulators.

Tonga's agricultural export marketing fund was allocated to three companies out of eleven applicants, indicating the eligibility conditions for exporters in the start-up phase was set high at New Zealand market standards. The uncertainty was; were the selected companies sustainable in respect of commercial competition with other Pacific Island countries exporting to New Zealand? Furthermore, did the state adequately resource processing and packaging support for commodities, rather than singly supplying cash to remunerate farmers for produce sales?

The Agricultural Export Marketing Fund aimed at providing short term loans to exporters who buy produce from farmers. Three agricultural produce exporting companies have been selected to access the funds. Produce that the fund will give priority to are taro, tapioca, watermelons, and yams. The three agricultural produce exporters who had been selected to 
access the fund were the Pacific Exotic Foods, Hammah Consulting and the Young Farmers Federation Ltd. (Matangi Tonga, 2013b).

In addition, the recruitment of a Tonga trade representative based in Auckland was a tall order. Instead of focusing on the representative's ability to trade with importers on the warehouse floor, the job advertisement was targeted at a policy analyst with legal and regulatory knowledge of international trade agreements. Which leads to the critical question, what was difficult about trading taro, tapioca, watermelon, and yam to New Zealand for Tongan farmers?

Candidates should have good knowledge and experience of international trade facilitation, market conditions in New Zealand, and New Zealand specific exports products protocols. The position will be most suitable for candidates who have working experience with Commodities Buyers in New Zealand and have insights knowledge of the New Zealand markets networks. It would be an advantage if the candidate is an indigenous Tongan residing in New Zealand with a good knowledge of SPARTECA, PACER, PACER Plus, as well as the terms and conditions of Tonga's membership to the WTO. (Government of Tonga, 2013).

\section{Watermelon story}

October of 2011, 'Inoke Teisi, a young farmer from Vaini told me his story. Smoking roll-your-own tobacco and standing by his bush allotment he explained why export trade was too burdensome a load for small-scale growers like him to carry. On a three acre plot he managed to cultivate root crops cassava, yam, kumara and kape - for his family's household consumption. Any surplus food Teisi grew and could sell on the local market was a bonus, generating much needed cash 
income. To move beyond subsistence cropping into commercial exporting required capital up front, at least ten thousand Tongan pa'anga for three to four acres of watermelon including road transport and sea freight. Plainly, he did not have the start up cash. He was ineligible for a bank loan. Nor could he raise the amount through his extended family.

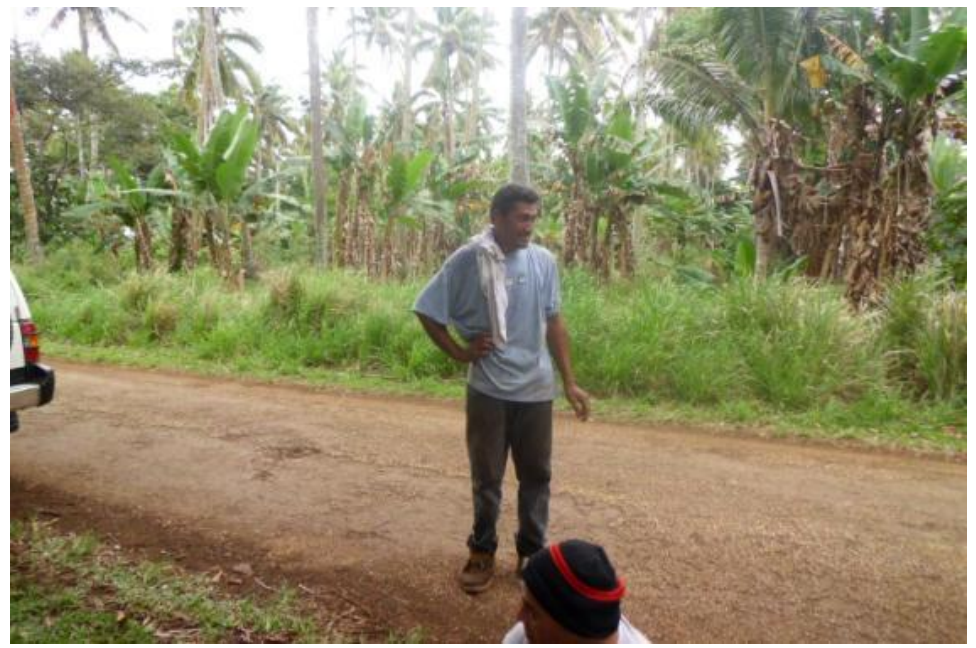

Vaini farmer, 'Inoke Teisi, who grows Tongan root crops on a three acre plot in the Kingdom of Tonga's central district.

Fifteen kilometres away from Vaini in the capital of Nuku'alofa, Tom Nakao, a local businessman, the son of Tom Nakao senior whose father was Japanese, sat in his office. At a desk with a laptop computer, he gave me his side of the watermelon story. The double roles he played in the government sector and the business sector testified that his involvement in agricultural trade was pervasive and powerful. First, he was an exporter. Second, his company was the Tonga agent for selling Terranova Seeds imported from Auckland, New Zealand. Third, he was board chairman for the state-owned enterprise Tonga Export Quality Management Limited, and his brother was the director. Tonga Export 
Quality Management Limited had the Government of Tonga contract to operate the forced air and heat treatment facility at Fua'amotu Domestic Airport, a facility paid for by New Zealand Aid. Fourth, he had an exclusive agreement with Direct Fresh Limited New Zealand, an Auckland distributor to New Zealand supermarket chains, to act as their sole supplier from Tonga for fresh and processed produce.

Fifth, he was a director at Growers Federation of Tonga Incorporated, the largest private sector organisation of Tongan farmers which claimed to have twelve hundred members, and had government backing (Haas, 2013b). Through this connection, he based himself in a Nuku'alofa office for the Growers Federation of Tonga Incorporated. Sixth, he was an executive member and market access coordinator for the Pacific Horticultural and Agricultural Market Access programme (PHAMA), a group of government employees and private sector exporters financed by Australian AID to get agricultural trade moving forward (Taimi Media, 2011; PHAMA, 2012). Seventh, he was a commissioner for the Public Service Commission, the Tongan state body in charge of restructuring the public sector and matters of human resource management.

If the adage of too many fingers in too many pies required a case study, then agricultural trade in Tonga created a fertile environment for this analogy to blossom and bear conflict of interest fruit. Tom Nakao worked across the industry, contravening the Western governance principle of best practice in the public sector, which was, for government to free up space for fair and openly contested private sector competition. Nakao together with an in-house group of exporters, Minoru Nishi of Nishi Trading Limited and Pousima Afeaki of Tinopai Farm, constituted private sector representatives on the Australian government's market access project, PHAMA (Taimi Media Network, 2011). Nishi like Nakao was descended from a Japanese grandfather who had migrated to Tonga, while 
Afeaki was of mixed Polynesian heritage, Tongan and New Zealand Maori (True Pacific, 2013).

From here, this business cluster of three men heading their companies doubled up as the Tonga Market Access Working Group (TMAWG). The working group was responsible for overseeing the Ministry of Agriculture (MAFFF) export pathway, a national system that made sure Tonga's commodities complied with Australian and New Zealand quarantine standards. They were Tonga's main businesses using the export pathway which meant, in actuality, they were evaluating government work conducted on their own supply chain. An elite group of men exerted control over the agricultural industry becoming renowned throughout Tonga and with Pacific Islands Trade and Invest (PITIC), the regional trade arm of the Pacific Islands Forum Secretariat, as the who's who in the zoo. ${ }^{1}$

In 2010, Nakao coordinated a trial for growing export watermelon using Vaini men as the small farmers in the experiment. He felt this particular group did not have the capability to get their crops up to the market access standard which the New Zealand Ministry of Agriculture demanded, and that the only real export farmers in Tonga were from Hahake, the eastern district of Tongatapu. Top-down views of ordinary people in small island developing states stir up histories from below, as Nakao's estimation did (Sharpe, 2001).

A counter narrative was conveyed by Vaini farmers struggling at the bottom of the production chain because, as Michel Foucault so aptly put it, resistance does not operate outside the realm of power, but rather, is a by-product of the dominant power structure in any given society (Foucault, 2002). Put simply, power excretes resistance out of its bottom end. In reality, the majority of people living in Tonga's rural villages, districts, and outer islands are confined to acts of resistance. They are systematically prevented from making a living above borderline poverty by a minority group on top guarding the privileged access to most of the country's land 
leases, resources, markets, networks, and wealth. In this predicament, ordinary people learn to be resilient in their dayto-day existence, coping with the limited opportunity for making cash income, as was 'Inoke Teisi's situation.

Teisi gave a compelling account of the Kingdom of Tonga's agricultural sector from how he had experienced the system and its discontents (Stiglitz, 2002). The landscape of small farms bordering his plot showed that local, not export produce was being grown. Farmers were burnt out and cautious about exporting, beleaguered by the middleman horde hocking off the best part of the profits. They were frustrated by the apathy and inactivity of successive governments. Over the years, various ministers for agriculture had not protected farming livelihoods, the country's economic backbone, by providing stimulus packages and to an extent, regulating the market to ensure that village and district farmers really get fair trade, a fair price for their harvest.

'Inoke Teisi spoke up with raw honesty. He was critical of middlemen exporters and government. Different to the businessmen who owned commercial trading companies, he had nothing to lose by way of assets, wealth, and reputation on the overseas market. He did not have an expansive territory to protect, and his opinions were not up for public scrutiny. He was not likely to feature in local media representing the farming industry.

Teisi recalled that for Tom Nakao's watermelon trial he was given $\$ 1,000$ Tongan pa'anga. This amount was for the cost of ploughing, seeds, fertiliser, irrigation, harvesting, and postharvesting labour. He was growing three acres of export watermelon. His entire plot was under trial. The real cost was one thousand Tongan pa'anga per acre. The total amount needed was in fact three thousand, and because one thousand does not add up to three, Teisi elected to cut costs by reducing the quantity of spraying and other insecticide treatment. His crop failed to produce export standard fruit. 
Worse than crop failure was the penalty; he said that he was made to remunerate $\$ 1,500$ Tongan pa'anga to Tom Nakao's company as repayment for the cash loaned to him for production costs. One thousand, the original sum the farmer was given, does not add up to fifteen hundred. Whether this happened how the account was relayed, I cannot determine. What I can say, however, is that penalising a small-scale farmer with an additional fee is indicative of the political economy. It represents the Tongan farmer's low ranking in the commercial hierarchy. It exemplifies the poor man's situation, buried under a compost heap of hidden costs on top of production costs, and borrowing money to cover both (Murray, 2001).

This small scenario had been replicated at a national scale through Tonga's commercial cropping debt which was incurred from the squash export losses of the 1990s and first decade of the 21 st century. Local farmers lost out to middlemen and bank foreclosure when the Asian squash market collapsed on top of them (Felemi, 2001; Kerry, 1993; van der Grijp, 1997). In this second decade of the 21 st century, agricultural trade continued looking unattractive. The government had no will to reorganise the system of trade. For Tonga's agricultural industry, creating a business environment supportive of smallscale growers collaborating as village cooperatives to compete fairly, and trade independently on the overseas market, was an ideal. But dismantling the purchasing power of a handful of exporters, who were accustomed to being the only option farmers had to sell to, who had built up business connections on the overseas market, was easier to conceive than put into systematic practice.

\section{Long distance nationalism}

In March of 2013 I had a disagreement on my mobile with Lord Ma'afu. I was in Tonga doing field research. Sitting in a Nuku'alofa café waiting for my order, a phone quarrel broke 
out between me and the Minister for Lands and Environment. He wanted me to "make peace" (his words) with a New Zealand ex-patriate working in Tonga whom I had fallen out with a couple of years back. At the time, the Kiwi in Tonga was exporting watermelon he had purchased from village growers to an Auckland importer. At the time, I thought he may have been better off returning to Auckland permanently.

Ma'afu insisted that I reconcile with the New Zealander, a manifestation of living in a small island society where a highlevel of mutual relationships is idealised, and resolving fracture is etiquette. I shifted into being an Aucklander at topgear, my home town of 1.4 million people where bust-ups and knock-downs are everyday life, and socialising with friends is not confined to an insular circle of half-a-dozen at the Nuku'alofa club.

"This is our country," Ma'afu exclaimed, signalling it was culturally warranted to show hospitality and kindness to foreigners, non-Tongans, visitors. "No Ma'afu, this is your country!" Instantaneously he countered; "Then what are you doing hanging around here?" That stung. I had no smartmouth Auckland comeback. I had been sent home by the noble of Vaini and Tokomololo for ignoring the signpost on social conduct.

In 2007, Benedict Anderson gave an interview on "longdistance nationalism" where he criticised the diaspora, the overseas clusters of migrants who had moved away from "countries of origin" for playing "long-distance politics" in homeland affairs (Charim, 2007). Anderson was scathing of migrants and their descendants being quick to fault national politics inside the countries "they come from" while living abroad, simply because the critic did not "have to assume responsibility" for the "consequences" of their words, sentiments, and actions (Charim, 2007). 


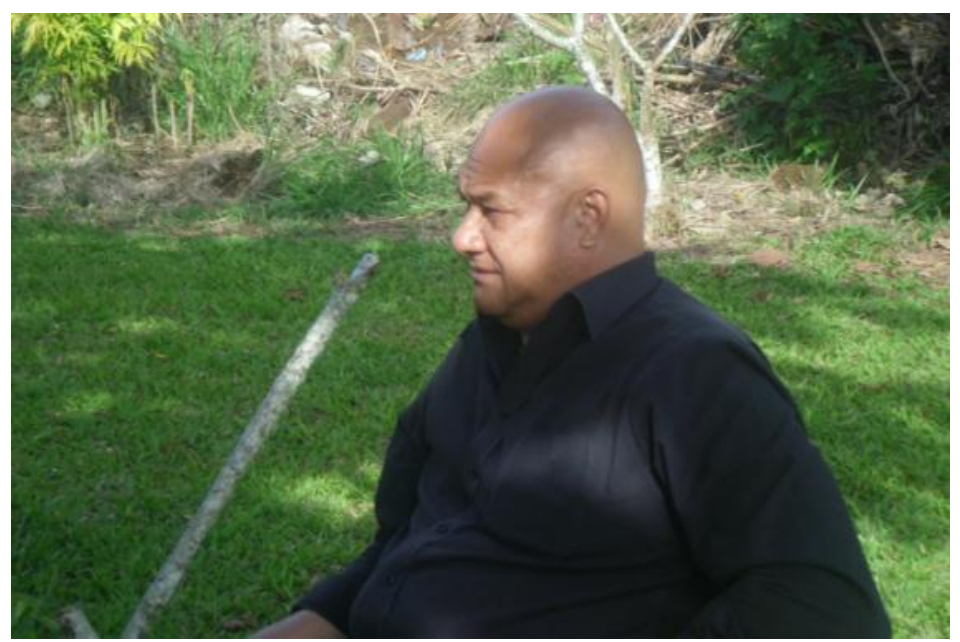

Lord Ma'afu, head of the Ha'a Havea Lahi and the noble of Vaini and Tokomololo, who holds the Government of Tonga portfolio as the Minister for Lands and Environment.

Today we have the long-distance nationalism of those who live in other countries. They often try to compensate with an exaggerated sense of pride for the country they come from. Mass communication has made this much easier than it once was. People can listen to the radio stations of their home countries, watch DVs, make telephone calls home, use cheap flights to visit regularly and so on. These people often want to participate in the politics of their countries of origin but don't have to obey the laws or pay the taxes. In a way they're free agents. People who engage in long-distance politics don't have to assume responsibility for its consequences (Charim, 2007).

Anderson could have been talking about me or any overseas Tongan critic who writes and performs social commentary for a living. This essay's title, she'll wake up one 
of these days and find she's turned into a Tongan, is a tonguein-cheek prod at myself (Bolatagici, 2004). It scans the selfabsorbed identity arguments I have with myself recognising that self-realisation came through researching the field, out in the farmlands of Vaini, a rural village I have no blood connection to, the moment I knew I am definitely a Tongan woman to stand up for farmers, the ordinary people without power and wealth (Featherstone, Henwood, and Parenti, 2013; Roy, 2001).

In closing, for me, if there is one aspect of writing development in 21 st century Tonga as an anthropologist, an academic researcher, which sets this small island developing state apart from others in the South Pacific, then it is people, individuals, leaders. For a democratised Kingdom that still stresses greatness in smallness, unity through homogeneity, cohesion by conformity with convention, the catch is that leadership of strong moral character is pivotal to structure and process (Sykes, 2010). And when the structure falls apart rendering the system dysfunctional and irrelevant to serving society's needs, it is indeed, as the former Prime Minister of Tonga Dr Feleti Sevele pointed out, because leadership "without a clear moral compass" has committed more harm than good (Matangi Tonga, 2013d).

For graduates from the developing countries, whilst education has opened up windows of opportunities for many, it has not solved all of our problems. Perhaps we, the privileged and educated few, need to be reminded that education without a clear moral compass can be a very dangerous thing. (Matangi Tonga, 2013d). 


\section{References}

Ahmed, S. (1999). 'She'll wake up one of these days and find she's turned into a nigger:' Passing through Hybridity. Theory, Culture and Society, 16 (2): 87-106.

Appadurai, A. (1996). Modernity at Large: Cultural Dimensions of Globalization. Minneapolis, USA: University of Minnesota Press.

Austin, T. (1993). I can picture the old home so clearly: The Commonwealth and Half-Caste Youth in the Northern Territory 1911-1939. Canberra, Australia: Aboriginal Studies Press.

Bender, B. (1999). Subverting the Western Gaze: Mapping Alternative Worlds. In The Archaeology and Anthropology of Landscape: Shaping Your Landscape, edited by P. Ucko and R. Layton. New York, USA: Routledge, Pp. 31-45.

Bhabha, H. K. (1997). Of Mimicry and Men: The Ambivalence of Colonial Discourse. In Tensions of Empire: Colonial Cultures in a Bourgeois World, edited by F. Cooper and A. L. Stoler. Berkeley and Los Angeles, California, USA: University of California Press, Pp. 152-197.

Bolatagici, T. (2004). Claiming the (n)either/(n)or of 'third space:' (re)presenting hybrid identity and the embodiment of mixed race. Journal of Intercultural Studies, 25 (1): 75-85.

Campbell, I. C. (2011). Tonga's Way to Democracy. New Plymouth, New Zealand: Herodotus Press.

Charim, I. (2007). Benedict Anderson on diaspora nationalism. Euro Topics, Bonn, Germany, August 6. Retrieved from

http://www.eurotopics.net/en/home/medienindex/media_articles/ar chiv_article/ARTICLE19423-Benedict-Anderson-on-diasporanationalism

Clifford, J. (1988). The Predicament of Culture: Twentieth Century Ethnography, Literature and Art. Cambridge, Massachusetts, USA: Harvard University Press.

Cooper, F. and A. L. Stoler. (Eds.) (1997). Tensions of Empire: Colonial Cultures in a Bourgeois World. Berkeley and Los Angeles, California, USA: University of California Press.

Cox, O. C. (1945). Race and Caste: A Distinction. American Sociology, 50 (5): 360-368.

Dabashi, H. (2013). Can non-Europeans think? Aljazeera, Doha, Qatar, January $15 . \quad$ Retrieved from

http://www.aljazeera.com/indepth/opinion/2013/01/201311414263 8797542.html

Ellis, C. and Berger, L. (2003). Their Story/My Story/Our Story. In Inside Interviewing: New Lenses, New Concerns, edited by J. Holstein and J. Gubrium. Thousand Oaks, California, USA: Sage Publications, Pp. 467-494.

Featherstone, L., Henwood, D. and Parenti, C. (2013). "Action Will Be Taken:" Left Anti- Intellectualism and Its Discontents. Radical Society, Taylor and Francis Group, United Kingdom, April 20. Retrieved from

http://www.leftbusinessobserver.com/Action.html 
Firth, S. (2000). The Pacific Islands and the Globalization Agenda. The ContemporaryPacific, 12 (1): 178-192.

Foucault, M. (2002). The Archaeology of Knowledge, translated by A. M. Sheridan Smith, First Published in 1969. London and New York: Routledge.

Gilbert, M., Richards-Rees, C., Spicer, N. and Coates, B. (2013). Sustainable Development in the Pacific and the Role of the New Zealand Private Sector, Oxfam Research Report, March, Auckland, New Zealand, Pp. 1-59.

Government of Tonga. (2013). Expression of Interest: Tonga Trade Representative, Auckland, New Zealand. Ministry of Commerce, Tourism and Labour, Nuku'alofa, Kingdom of Tonga, March 18. Retrieved from

http://www.mctl.gov.to/?p=1709

Haas, A. (2013a). 'Aisake Eke MP uses Pacific Parliament to push Tongan produce exportto NZ. Tonga NZ Net, Auckland, New Zealand, April 18. Retrieved from

http://www.tonganz.net/home/aisake-eke-mp-uses-pacificparliament-to-push-tongan-produce-export-to-nz/

Haas, A. (2013b). Sangster Saulala's one million dollar agricultural fund. Tonga NZ Net, Auckland, New Zealand, April 20. Retrieved from

http:/ / www.tonganz.net/home/sangster-saulalas-one-million-dollaragricultural-fund/

Haas, A. (2013c). Fakafanua's priorities at Pacific Parliament 2013. Tonga NZ Net, Auckland, New Zealand, April 20. Retrieved from

http://www.tonganz.net/home/fakafanuas-priorities-at-pacificparliament-2013/

Haas, A. (2013d). We don't yet have a Pacific parliament, but ... Tonga NZ Net, Auckland, New Zealand, April 22. Retrieved from

http:/ / www.tonganz.net/home/we-dont-yet-have-a-pacificparliament-but/

Hau'ofa, 'E. (1987). The New South Pacific Society: Integration and Independence. In Class and Culture in the South Pacific, edited by A. Hooper. Auckland and Suva: Centre for Pacific Studies, University of Auckland, and the Institute of Pacific Studies, University of the South Pacific.

Hau'ofa, 'E. (1993). Our Sea of Islands. In A New Oceania: Rediscovering Our Sea of Islands, edited by E. Waddell, V. Naidu, and 'E Hau'ofa. Suva, Fiji: School of Social and Economic Development, University of the South Pacific.

Hau'ofa, 'E. (2008). We are the Ocean: Selected Works. Honolulu, Hawai'i, USA: University of Hawai'i Press.

Hayes, J. (2013). Pacific Parliamentary Forum Closes with a Call for Action, Press Release: Foreign Affairs, Defence and Trade Committee. New Zealand Parliament, Wellington, New Zealnd, 
April 23. Posted by Scoop Independent News, Auckland, New

Zealand. Retrieved from

http://www.scoop.co.nz/stories/PA1304/S00441/pacific-

parliamentary-forum-closes-with-call-for-action.htm

Herndon, T., Ash, M. and Pollin, R. (2013). Does High Public Debt

Consistently Stifle Economic Growth? A Critique of Reinhart and Rogoff. Working Paper Series, 332 (April): 1-26, Political Economy Research Institute, University of MassachusettsAmherst.

Howe, K. R., Kiste, R. C. and Lal, B. V. (Eds.) (1994). Tides of History: The Pacific Islands in the Twentieth Century. Honolulu, Hawai'i, USA: University of Hawai'i Press.

Kennedy, K. H. (2012). Why Land Tenure Reform is the Key to Political Stability in Tonga. Pacific Rim Law and Policy Journal Association, 12 (2): 327-362.

King, M. L. (1963). Strength to Love. Minneapolis, USA: Augsburg Fortress Publishers.

Larsen, N. (1929). Passing. New York, USA: Knopf Publishing.

Latukefu, S. (1974). Church and State in Tonga: The Wesleyan Methodist Missionaries and Political Development, 1822-1875. Canberra, Australia: Australian National University Press.

McGregor, R. (1993). Representations of the half-caste in the Australian scientific literature of the 1930s. Journal of Australian Studies, 17 (36): 51-64.

Ministry of Finance and National Planning. (2012). Applications for the Agricultural Export Marketing Fund. Government of Tonga, Nuku'alofa, Kingdom of Tonga, November 13. Retrieved from

http://www.finance.gov.to/content/applications-agricultural-exportmarketing-fund

Marsh, S. T. (2009). Fast Talking PI. Auckland, New Zealand: Auckland University Press.

Matangi Tonga. (2013a). Tonga Govt launches \$1 million Agricultural Fund for exports. Matangi Tonga Online, Nuku'alofa, Kingdom of Tonga, February 8. Retrieved from

http:/ / matangitonga.to/2013/02/08/tonga-govt-launches-1-millionagricultural-fund-exports

Matangi Tonga. (2013b). PM announces tax exemption for fisheries. Matangi Tonga Online, Nuku'alofa, Kingdom of Tonga, April 14. Retrieved from

http://matangitonga.to/2013/04/14/pm-anounces-tax-exemptionfisheries

Matangi Tonga. (2013c). Changing laws, changing attitudes - new Family Protection Bill aims to stop violence. Matangi Tonga Online, Nuku'alofa, Kingdom of Tonga, April 19. Retrieved from

http:/ / matangitonga.to/2013/04/19/changing-laws-changingattitudes-new-family-protection-bill-aims-stop-violence 
Matangi Tonga. (2013d). Canterbury University awards Honorary Doctorate to Tonga's Lord Sevele. Matangi Tonga Online, Nuku'alofa, Kingdom of Tonga, April 24. Retrieved from

http://matangitonga.to/2013/04/24/canterbury-university-awardshonorary-doctorate-tongas-lord-sevele

Murray, W. E. (2001). The second wave of globalisation and agrarian change in the Pacific Islands. Journal of Rural Studies, 17 (2): 135-148.

Oliver, D. L. (1989). The Pacific Islands. Honolulu, Hawai'i, USA: University of Hawai'i Press, Third Edition.

Pieterse, J. N. (2001). Hybridity, So What? The Anti-Hybridity Backlash and the Riddles of Recognition. Theory, Culture and Society, 18 (2-3): 219-245.

PHAMA. (2012). PHAMA Phase 1, $80 \%$ done - so how are things tracking? Tonga Government Portal, Ministry of Information and Communications, Nuku'alofa, Kingdom of Tonga, December 4. Retrieved from

http://www.mic.gov.to/news-today/press-releases/4155-pharmaphase-1-80-done-so-how-are-things-tracking

Pollin, R. and Ash, M. (2013). Reinhart and Rogoff are wrong about austerity. Political Economy Research Institute, University of Massachusetts Amherst, April 17.

Roy, A. (2001). The Algebra of Infinite Justice. The Progressive, Madison, Wisconsin, USA. Posted on Third World Traveler, USA, December. Retrieved from

http://www.thirdworldtraveler.com/Arundhati_Roy/Algebra_InfiniteJ ustice_Roy.htm

Sergel, M. and Scott, F. (2013a). 'Hypocritical' NZ told to stop fatty food exports to Pacific. Pacific Scoop: AUT's Pacific Media Centre, Auckland, New Zealand, April 20. Retrieved from

http://pacific.scoop.co.nz/2013/04/hypocritical-nz-told-to-stop-fattyfood-exports-to-pacific/

Sergel, M. and Scott, F. (2013b). Pacific leaders reject World Bank, NZ push to free up trade. Pacific Scoop: AUT's Pacific Media Centre, Auckland, New Zealand, April 22. Retrieved from

http://pacific.scoop.co.nz/2013/04/pacific-leaders-reject-world-banknz-push-to-free-up-trade/

Sergel, M. and Scott, F. (2013c). Vanuatu minister calls for 'enshrining' of custom land tenure to protect Pacific. Pacific Scoop: AUT's Pacific Media Centre, Auckland, New Zealand, April 23. Retrieved from

http:/ / pacific.scoop.co.nz/2013/04/vanuatu-minister-calls-forenshrining-of-custom-land-tenure-to-protect-pacific/

Sharpe, J. (2001). History from Below. In New Perspectives on Historical Writing, edited by P. Burke. Philadelphia, USA: Pennsylvania State University Press, Second Edition.

Stiglitz, J. (2002). Globalization and Its Discontents. New York, USA: W. W. Norton andCompany Incorporated. 
Stonequist, E. V. (1935). The Problem of the Marginal Man. The American Journal of Sociology, 41 (1): 1-12.

Stonequist, E. V. (1937). The Marginal Man: A Study in Personality and Culture Conflict. New York, USA: Scribner's Sons.

Sykes, A. (2010). Annette Sykes: Bruce Jesson Foundation Lecture. University of Auckland, Auckland, New Zealand, Pp. 1-36. Retrieved from

http://img.scoop.co.nz/media/pdfs/1011/Annette_Sykes_Lecture_20 10.pdf

Taimi Media. (2011). PHAMA launched in Tonga. Taimi Media Network, Nuku'alofa, Kingdom of Tonga, June 3. Retrieved from

http:/ / www.taimionline.com/articles/4011

Tonga Land Act. (1988). Tonga Land Act: 1988 Revised Edition, Kingdom of Tonga, Pp. 1- 114.

True Pacific. (2013). Tinopai Produce Growing in Stature. True Pacific: The Best of the Pacific, Pacific Cooperation Foundation, Auckland, New Zealand, April 23. Retrieved from

http://www.truepacific.com/news-stories/news-2013/tinopaiproduce-growing-in-stature.html

van der Grijp, P. (1997). Leaders in Squash Export: Entrepreneurship and the Introduction of a New Cash Crop in Tonga. Pacific Studies, 20 (1): 29-62.

Wallerstein, I. (1976). The Modern World-System: Capitalist Agriculture and the Origins of the European World-Economy in the Sixteenth Century. New York, USA: Academic Press.

Williams, B. F. (1995). Classification Systems Revisited: Kinship, Caste, Race, and Nationality as the Flow of Blood and the Spread of Rights. In Naturalizing Power: Essays in Feminist Cultural Analysis, edited by S. Yanagisako and C. Delaney. London, United Kingdom: Routledge, Pp. 201-236.

\section{Photographs}

Auckland, New Zealand, Teena Brown Pulu, 2011.

Vaini, Kingdom of Tonga, Teena Brown Pulu, 2011.

Auckland, New Zealand, Melino Maka, 2013.

Auckland, New Zealand, Melino Maka, 2006.

Vaini, Kingdom of Tonga, Teena Brown Pulu, 2011.

Vaini, Kingdom of Tonga, Teena Brown Pulu, 2011.

Vaini, Kingdom of Tonga, Teena Brown Pulu, 2011.

\section{Tongan glossary}

Pakeha NZ Maori reference to European, meaning a white person/people.

Palangi Tongan reference to European, meaning a white person/people.

'Uta Bush allotment in Tonga used for a plantation. 


\section{Endnote}

1 The reference to who's who in the zoo is taken from the Master of Philosophy research proposal of Richard Pamatatau, Pacific journalism lecturer in the School of Communication Studies at AUT University. Pamatatau proposed to analyse the weekend social pages of two leading New Zealand newspapers, and by collating data on who appeared with whom at what event, evidence the discourse of who's who in contemporary New Zealand society.

This essay's use of Pamatatau's social referent is a tongue-incheek observation of how social stratification is created from the business of agricultural trade in Tonga. There are two obvious tiers in Tongan society operating within the political economy of exporters and growers. The business conditions are right for exporters to accumulate assets and cash to produce more wealth, allowing an insular group of individuals to sustain their privileged position of economic ascendancy in a small island developing state where the unequal distribution of wealth between rich exporter and poor farmer is overpowering. By contrast, the growers, meaning the small-scale village farmers, consume capital to cultivate crops that barely recover their production costs. 